\title{
Polyoxometalate-based Photoactive Hybrid: uncover the first crystal structure of covalently linked hexavanadate-porphyrin molecule
}

Yingting Zhu,${ }^{\dagger}$ Yichao Huang, ${ }^{\dagger *}$ Qi Li,${ }^{\dagger}$ Dejin Zang, ${ }^{\dagger}$ Jing Gu,,${ }^{* *}$ Yajie Tang,,${ }^{\S}$ and Yongge $\mathrm{Wei}^{\dagger *}$

$\dagger$ Key Lab of Organic Optoelectronics \& Molecular Engineering of Ministry of Education, Department of Chemistry, Tsinghua University, Beijing 100084, China.

\$ Department of Chemistry and Biochemistry, San Diego State University, 5500 Campanile Drive, San Diego, CA 92182-1030, USA

$\S$ Key Laboratory of Fermentation Engineering (Ministry of Education), Hubei Provincial Cooperative Innovation Center of Industrial Fermentation, Hubei Key Laboratory of Industrial Microbiology, Hubei University of Technology, Wuhan 430068, P. R. China.

\author{
*Corresponding Author: \\ E-mail: yichaoh@126.com (Y.C.H.) \\ E-mail: yonggewei@mail.tsinghua.edu.cn (Y.G.W.) \\ E-mail: jgu@sdsu.edu (J.G.)
}




\section{Contents}

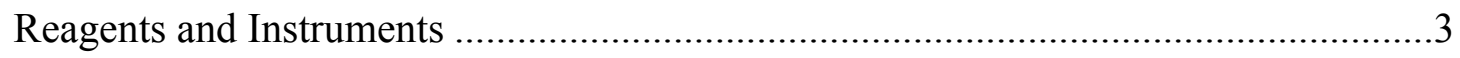

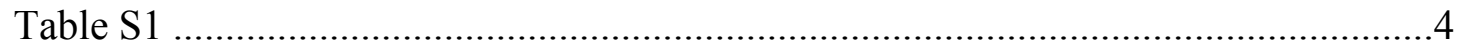

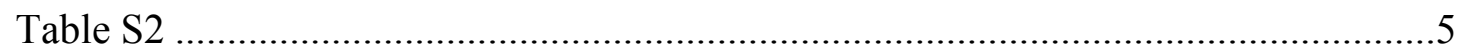

1. Synthesis of Porphyrin Organic Building Blocks .................................................6

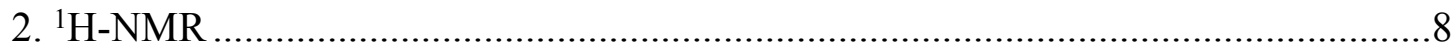

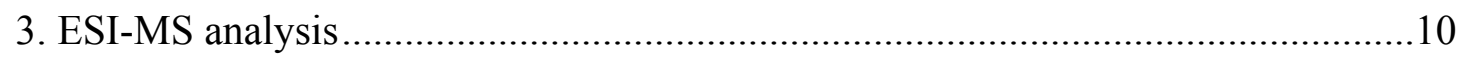

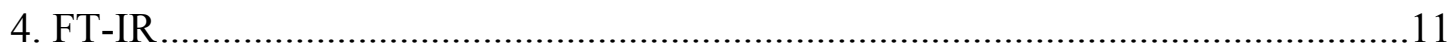

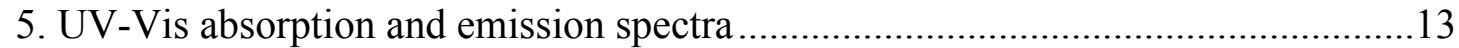

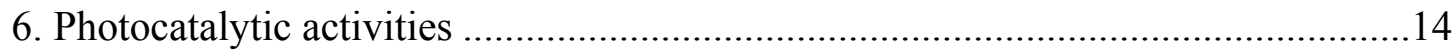

7. FT-IR spectra before and after photocatalysis ....................................................... 18

8. Energy bandgap calculation and CV results .........................................................19

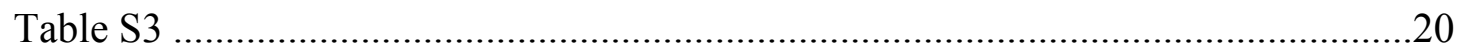

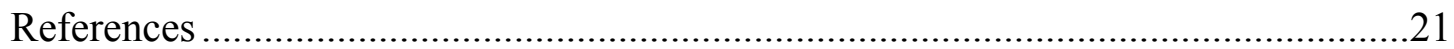




\section{Reagents and Instruments}

All reagents were purchased without further treatment except dimethylacetamide (DMAC). DMAC was dried with calcium hydride before use. ${ }^{1} \mathrm{H}-\mathrm{NMR}$ spectra were recorded using a JEOL JNM-EXC 400 spectrometer. ESI-MS spectra were recorded on a Thermo Q Exactive spectrometer. UV-Vis spectra were recorded on a UNICO UV$2102 \mathrm{PC}$ spectrophotometer in the range $300-800 \mathrm{~nm}$. Elemental analysis was measured with Elementar Vario EL III element analyzer. Infrared spectroscopy was recorded on a Bruker Vertex FT-IR spectrometer with a diamond ATR mode in the range of 600-4000 $\mathrm{cm}^{-1}$. V6 represents $\left(\mathrm{Bu}_{4} \mathrm{~N}\right)_{2}\left[\mathrm{~V}_{6} \mathrm{O}_{13}\left\{\left(\mathrm{OCH}_{2}\right)_{3} \mathrm{CCH}_{2} \mathrm{OH}\right\}_{2}\right]$, which was prepared according to the reference..$^{1,2}$ 


\section{Table S1}

Table S1. Crystal data and structure refinement for compound 2.

\begin{tabular}{|c|c|}
\hline Compound & 2 \\
\hline CCDC No. & 1961099 \\
\hline Empirical formula & $\mathrm{C}_{176} \mathrm{H}_{170} \mathrm{~N}_{12} \mathrm{O}_{23} \mathrm{P}_{2} \mathrm{~V}_{6} \mathrm{Zn}_{2}$ \\
\hline Formula Weight & 3319.55 \\
\hline Crystal Size $\left[\mathrm{mm}^{3}\right]$ & $0.300 \times 0.300 \times 0.040$ \\
\hline$T[\mathrm{~K}]$ & $293(2)$ \\
\hline$\lambda[\AA]$ & 1.54184 \\
\hline Crystal system & monoclinic \\
\hline Space group & $P 2_{1} / \mathrm{c}$ \\
\hline$a[\AA]$ & $23.8905(7)$ \\
\hline$b[\AA]$ & $15.7761(3)$ \\
\hline$c[\AA]$ & $28.8721(8)$ \\
\hline$\alpha\left[^{\circ}\right]$ & 90 \\
\hline$\beta\left[^{\circ}\right]$ & $104.740(3)$ \\
\hline$\gamma\left[^{\circ}\right]$ & 90 \\
\hline $\mathrm{V}\left[\AA^{3}\right]$ & $10523.7(5)$ \\
\hline$Z$ & 2 \\
\hline$\rho_{\text {calcd }}\left[\mathrm{g} \mathrm{cm}^{-3}\right]$ & 1.048 \\
\hline$\mu\left[\mathrm{mm}^{-1}\right]$ & 2.971 \\
\hline $\mathrm{F}(000)$ & 3444 \\
\hline$\theta$ range $\left[{ }^{\circ}\right]$ & 3.532 to 67.509 \\
\hline Reflections collected & 40650 \\
\hline Independent reflections & $18924\left[R_{\mathrm{int}}=0.0697, R_{\text {sigma }}=0.1306\right]$ \\
\hline$R_{1}[I>2 \sigma(I)]^{\mathrm{a}}$ & $\mathrm{R}_{1}=0.0958, \mathrm{wR}_{2}=0.2353$ \\
\hline $\mathrm{w} R_{2}$ (all data) $)^{\mathrm{b}}$ & $\mathrm{R}_{1}=0.1413, \mathrm{wR}_{2}=0.2680$ \\
\hline GOF on $F^{2}$ & 1.013 \\
\hline
\end{tabular}




\section{Table S2}

Table S2. Hydrogen bonding interactions and $\mathrm{C}-\mathrm{H} \cdots \pi$ interactions of compound 2.

\begin{tabular}{|c|c|c|c|c|}
\hline H-Bonds & $\mathrm{D}-\mathrm{A}[\AA]$ & A...H $[\AA]$ & D-H...A [०] & Labels \\
\hline C74-H74...O9 & 3.17 & 2.33 & 151.24 & $\mathrm{~d} 2$ \\
\hline C86-H86...O10 & 3.40 & 2.69 & 133.88 & $\mathrm{~d} 3$ \\
\hline C-H $\cdots \pi$ interactions & C-center $[\AA ̊]$ & 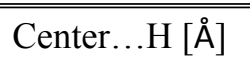 & "C-H...Center [०] & Labels \\
\hline  & 3.62 & 2.81 & 147.03 & $\mathrm{~d} 1$ \\
\hline C41-H41b $\cdots$ PlaneC32-C37 & 4.13 & 3.19 & 164.19 & $\mathrm{~d} 4$ \\
\hline C60-H60b $\cdots$ PlaneC42-C47 & 4.05 & 3.37 & 130.07 & $\mathrm{~d} 5$ \\
\hline
\end{tabular}




\section{Synthesis of Porphyrin Organic Building Blocks}

The general synthetic process of the porphyrins is shown in the scheme below.
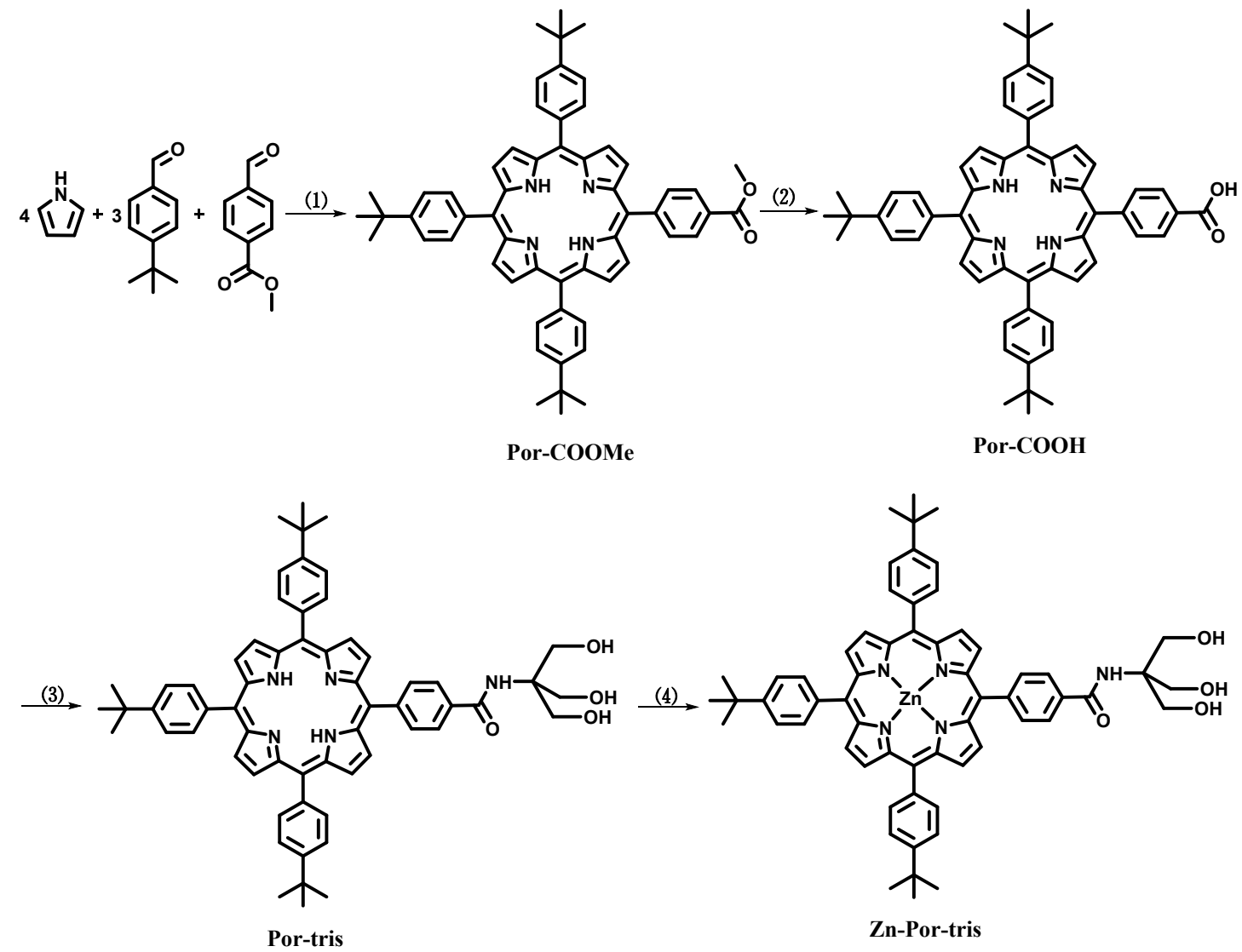

Scheme S1. Synthetic Scheme of the Porphyrin Building Blocks. (1) $\mathrm{BF}_{3} \cdot \mathrm{OEt}_{2}, \mathrm{DDQ}$, $\mathrm{CH}_{2} \mathrm{Cl}_{2}, \mathrm{RT}$; (2) $\mathrm{CH}_{3} \mathrm{CH}_{2} \mathrm{OH}, \mathrm{NaOH}$, reflux; (3) Tris, DMAC, EEDQ, $60^{\circ} \mathrm{C}$; (4) $\mathrm{Zn}(\mathrm{OAc})_{2} \cdot 2 \mathrm{H}_{2} \mathrm{O}, \mathrm{CHCl}_{3} / \mathrm{CH}_{3} \mathrm{OH}$, reflux.

Synthesis of Por-COOMe and Por-COOH. Por-COOMe and Por-COOH are synthesized according to the previously literature. ${ }^{3}{ }^{1} \mathrm{H}$ NMR of Por-COOMe $\left(\mathrm{CDCl}_{3}\right.$, $400 \mathrm{MHz}, \mathrm{RT})[\delta(\mathrm{ppm})]:-2.76(\mathrm{~s}, 2 \mathrm{H}), 1.61(\mathrm{~s}, 27 \mathrm{H}), 4.12(\mathrm{~s}, 3 \mathrm{H}), 7.77(\mathrm{~d}, 2 \mathrm{H}), 8.14$ $(\mathrm{d}, 6 \mathrm{H}), 8.32(\mathrm{~d}, 2 \mathrm{H}), 8.44(\mathrm{~d}, 2 \mathrm{H}), 8.77(\mathrm{~d}, 2 \mathrm{H}), 8.88(\mathrm{~m}, 6 \mathrm{H})$. ESI-MS $\left(\mathrm{C}_{58} \mathrm{H}_{56} \mathrm{~N}_{4} \mathrm{O}_{2}\right)$ : $[\mathrm{M}+\mathrm{H}]^{+}, 841.4 ;{ }^{1} \mathrm{H}$ NMR of Por-COOH $\left(\mathrm{CDCl}_{3}, 400 \mathrm{MHz}, \mathrm{RT}\right)[\delta(\mathrm{ppm})]:-2.76(\mathrm{~s}$, 2H), $1.61(\mathrm{~s}, 27 \mathrm{H}), 7.77(\mathrm{~d}, 6 \mathrm{H}), 8.15(\mathrm{~d}, 6 \mathrm{H}), 8.35(\mathrm{~d}, 2 \mathrm{H}), 8.50(\mathrm{~d}, 2 \mathrm{H}), 8.77(\mathrm{~d}, 2 \mathrm{H})$, $8.88(\mathrm{~m}, 6 \mathrm{H}) ; \mathrm{ESI}-\mathrm{MS}\left(\mathrm{C}_{57} \mathrm{H}_{54} \mathrm{~N}_{4} \mathrm{O}_{2}\right):[\mathrm{M}+\mathrm{H}]^{+}, 827.4$. 
Synthesis of Por-tris. Mixture of Por-COOH ( $1 \mathrm{~g}, 1.2 \mathrm{mmol})$, Tris (1.2 eq,180 mg), EEDQ (1.2 eq, $360 \mathrm{mg})$, DMAC $(24 \mathrm{~mL})$ in a $50 \mathrm{~mL}$ round bottle was stirred for $20 \mathrm{~h}$ at $60{ }^{\circ} \mathrm{C}$. After the reaction temperature was cooled down to the room temperature, the mixture was dropped into $500 \mathrm{~mL}$ deionized water and the resulted purple precipitate was collected by centrifugation and dried. The crude product was dissolved in a small amount $\mathrm{CHCl}_{3}$ and purified with column chromatography with $\mathrm{CH}_{3} \mathrm{OH} /$ dichloromethane $=4 \%$ (v:v) as eluent. The pure purple product of Por-tris was obtained by crystallization in pentane $(\mathrm{m}=668 \mathrm{mg}$, yield $=60 \%)$.

${ }^{1} \mathrm{H}$ NMR of Por-tris $\left(\mathrm{d}_{6}-\mathrm{DMSO}, 400 \mathrm{MHz}, \mathrm{RT}\right)[\delta(\mathrm{ppm})]:-2.92$ (s, pyrrole NH, 2H), $1.58\left(\mathrm{~s}, \mathrm{CH}_{3}, 27 \mathrm{H}\right), 3.85\left(\mathrm{~d}, \mathrm{CH}_{2}, 6 \mathrm{H}\right), 4.90(\mathrm{~s}, \mathrm{OH}, 3 \mathrm{H}), 7.70(\mathrm{~s}, \mathrm{NH}, 1 \mathrm{H}), 7.85(\mathrm{~d}, \mathrm{Ar}-$ $\mathrm{H}, 6 \mathrm{H}), 8.16$ (d, Ar-H, 6H), 8.30 (q, Ar-H, 4H), 8.85 (m, pyrrole-H, 8H); ESI$\operatorname{MS}\left(\mathrm{C}_{61} \mathrm{H}_{63} \mathrm{~N}_{5} \mathrm{O}_{4}\right)$ : [M-1], 928.4. UV-vis(DMF)[ $\left.\lambda_{\max } / \mathrm{nm}\right]: 418$ (Soret band), 515 550, 593, 648(Q bands); FT-IR(diamond)[ $\mathrm{cm}^{-1}$ ]: 3309(w), 2956(m), 2900(w), 2866(w), 1656(w), 1649(w), 1643(m), 1608(w), 1535(w), 1500(w), 1473(m), 1396(w), 1348(w), 1267(w), 1222(w), 1193(w), 1109(m), 1024(m), 1010(w), 993(w), 981(w), 966(s), 798(s), 733(s), 710(w). 


\section{2. ${ }^{1}$ H-NMR}

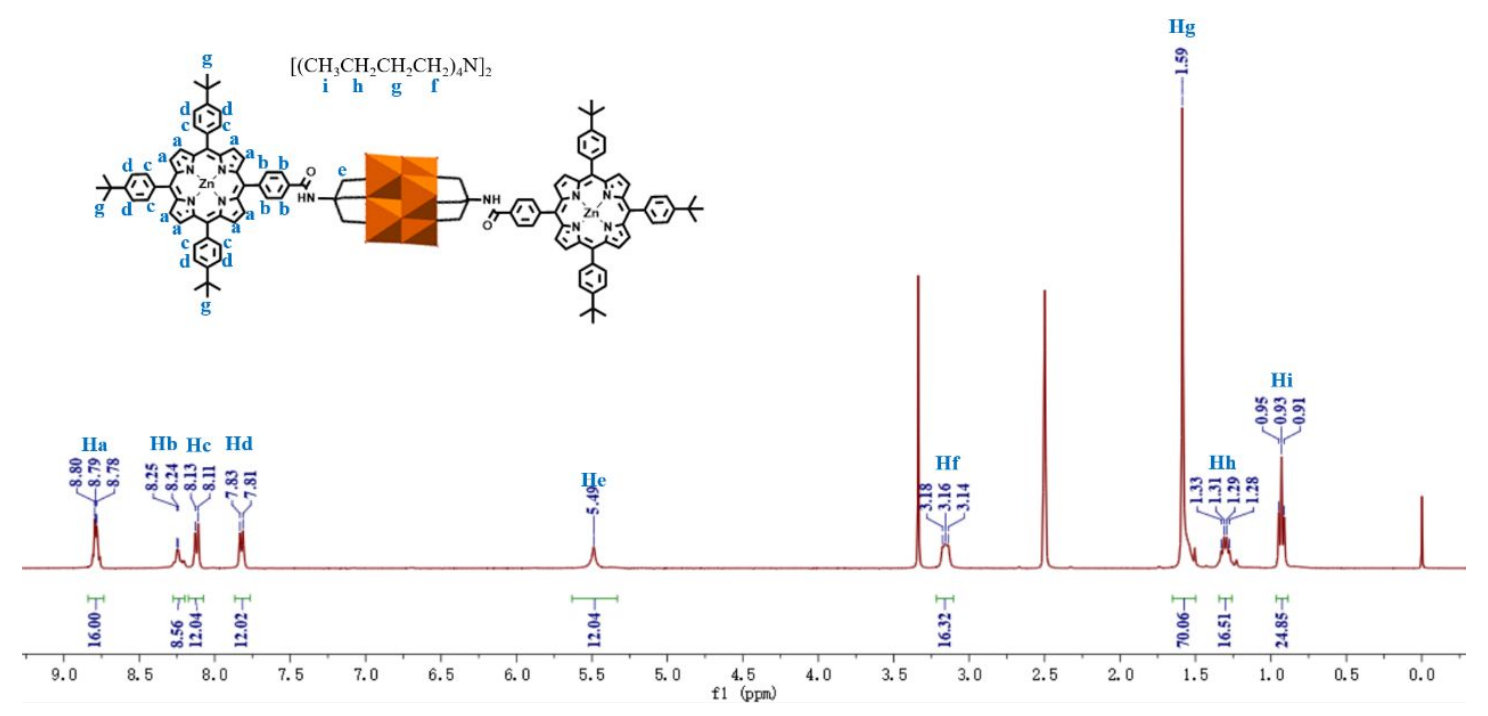

Figure S1. ${ }^{1} \mathrm{H}-\mathrm{NMR}$ spectrum of Compound 1.

${ }^{1} \mathrm{H}-\mathrm{NMR}$ signals assignment for compound 1: The peaks from downfield to highfield are labeled Ha to Hi. The multiple signal at $8.80 \mathrm{ppm}(\mathrm{Ha})$ is assigned to the peripheral $\mathrm{H}$ of the four pyrrole rings. The multiplet signal at $8.25 \mathrm{ppm}(\mathrm{Hb})$ is the $\mathrm{H}$ of benzene ring which is connected with the amide group. The double peaks at 8.118.13ppm $(\mathrm{Hc})$ and 7.81-7.83ppm $(\mathrm{Hd})$ are the inner $\mathrm{H}$ and outer $\mathrm{H}$ of benzene ring, respectively. The single peak at 5.49ppm $(\mathrm{He})$ is the methylene $\mathrm{H}$. The triplet at 3.14$3.18 \mathrm{ppm}$ (Hf) is the methylene $\mathrm{H}$ in tetrabutyl ammonium (TBA). The single peak at $1.59 \mathrm{ppm}(\mathrm{Hg})$ is the combination of peripheral tertiary butyl and partly methylene of TBA. The multiple peak at 1.28-1.33ppm ( $\mathrm{Hh})$ is the methylene $\mathrm{H}$ in TBA. The triplet signal at $0.91-0.95 \mathrm{ppm}$ (Hi) is the methyl $\mathrm{H}$ in TBA. 


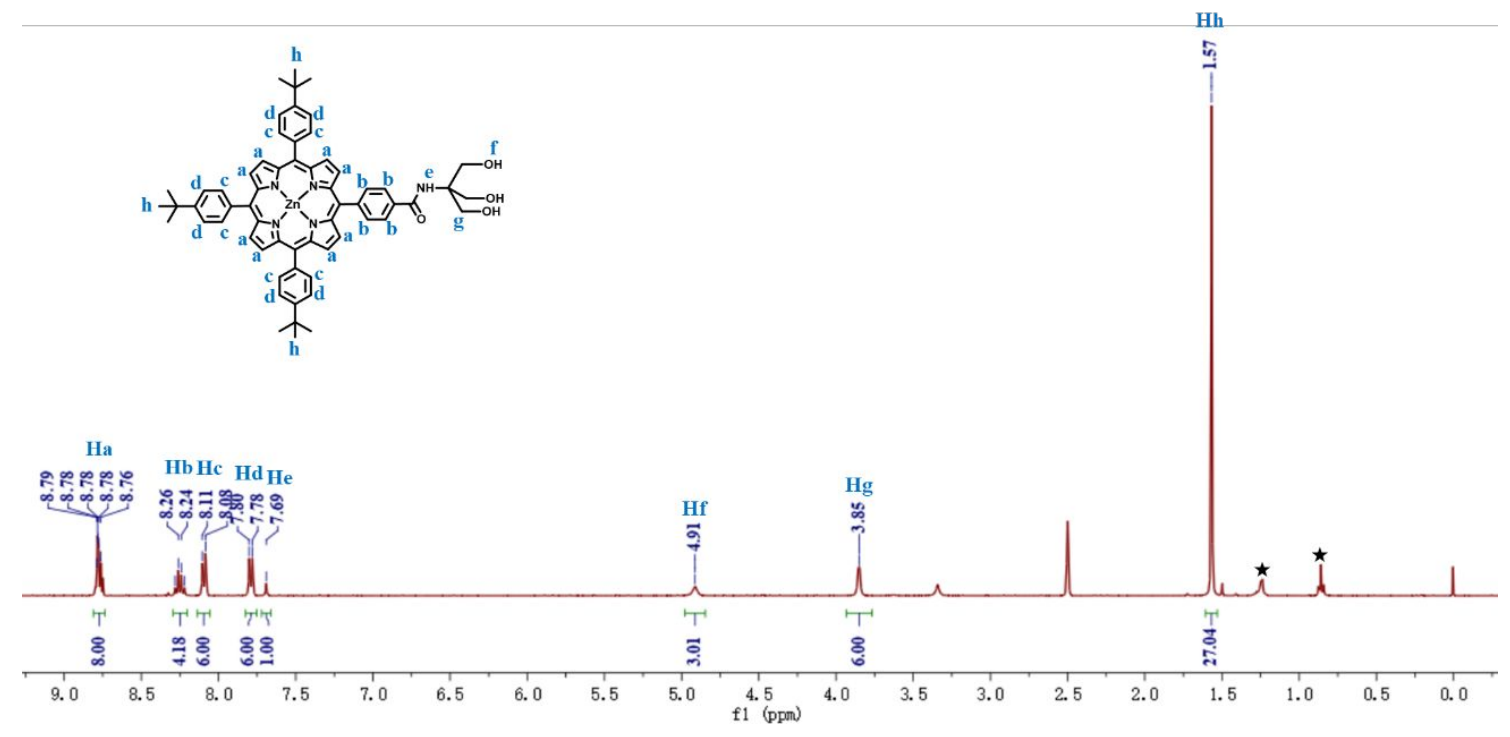

Figure S2. ${ }^{1} \mathrm{H}-\mathrm{NMR}$ spectrum of Zn-Por-tris.

${ }^{1} \mathrm{H}-\mathrm{NMR}$ signal assignments for Zn-Por-tris: The peaks from downfield to high-field are labeled Ha to $\mathbf{H h}$. The multiple signal at $\sim 8.78 \mathrm{ppm}$ (Ha) is assigned to the peripheral $\mathrm{H}$ of the four pyrrole rings. The quadruple signal at $8.22-8.28 \mathrm{ppm}(\mathrm{Hb})$ is the $\mathrm{H}$ of benzene ring which is connected with the amide group. The double peaks at 8.08-8.11 ppm ( $\mathrm{Hc})$ and 7.78-7.80ppm $(\mathrm{Hd})$ are the inner $\mathrm{H}$ and outer $\mathrm{H}$ of benzene ring, respectively. The minor single peak at $7.70 \mathrm{ppm}(\mathrm{He})$ is the $\mathrm{NH}$ of the amide group. The signal at 4.90ppm (Hf) is $\mathrm{OH}$. The peak at $3.85 \mathrm{ppm}(\mathrm{Hg})$ is the methylene $\mathrm{H}$. The single peak at $1.57 \mathrm{ppm}(\mathrm{Hh})$ is the $\mathrm{H}$ of peripheral tertiary butyl. The signal at 0.86 and $1.25 \mathrm{ppm}$ labeled by $\star$ is the residue of $\mathrm{n}$-hexane used in the recrystallization process. 


\section{ESI-MS analysis}

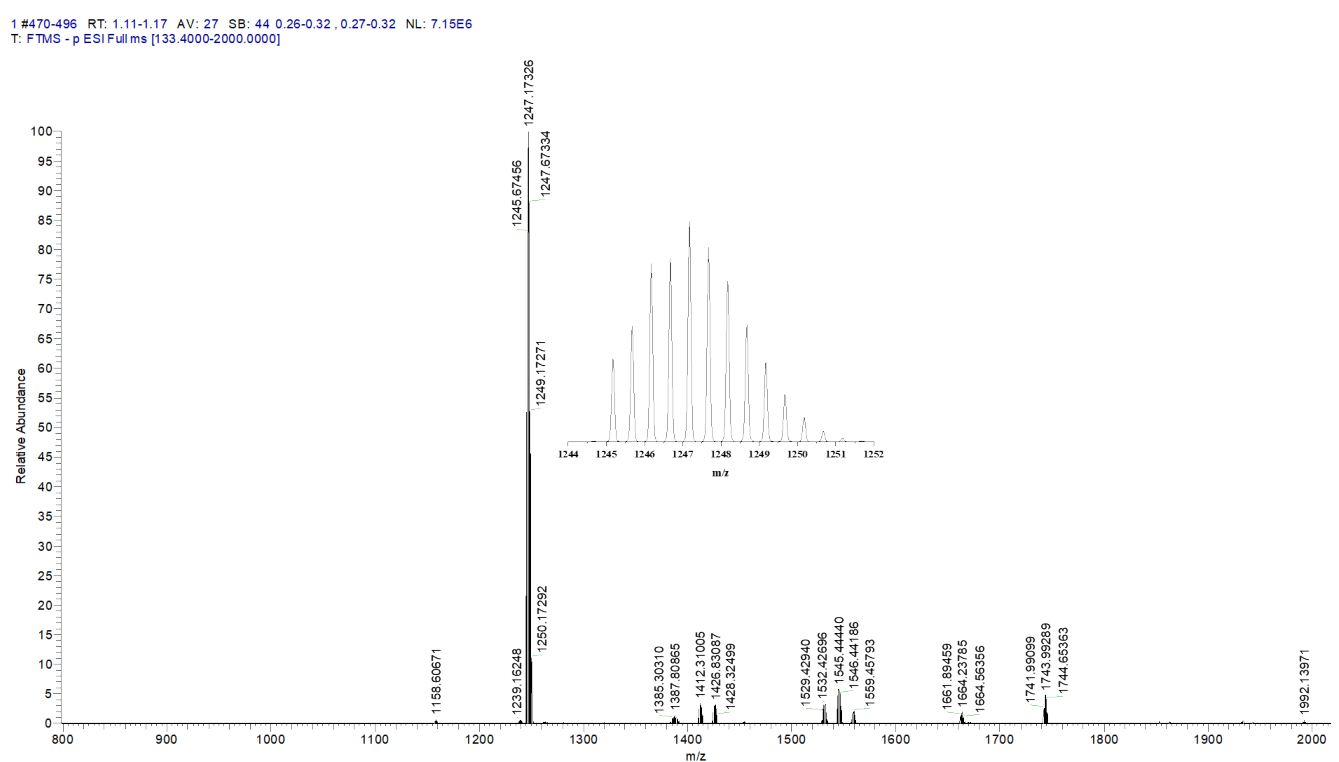

Figure S3. ESI-MS spectrum of compound 1 using the crystal precipitated from the liquid-diffusion solution of DMF/ diethyl ether. The inset is the enlarged part of $\mathrm{m} / \mathrm{z}=1247.17$.

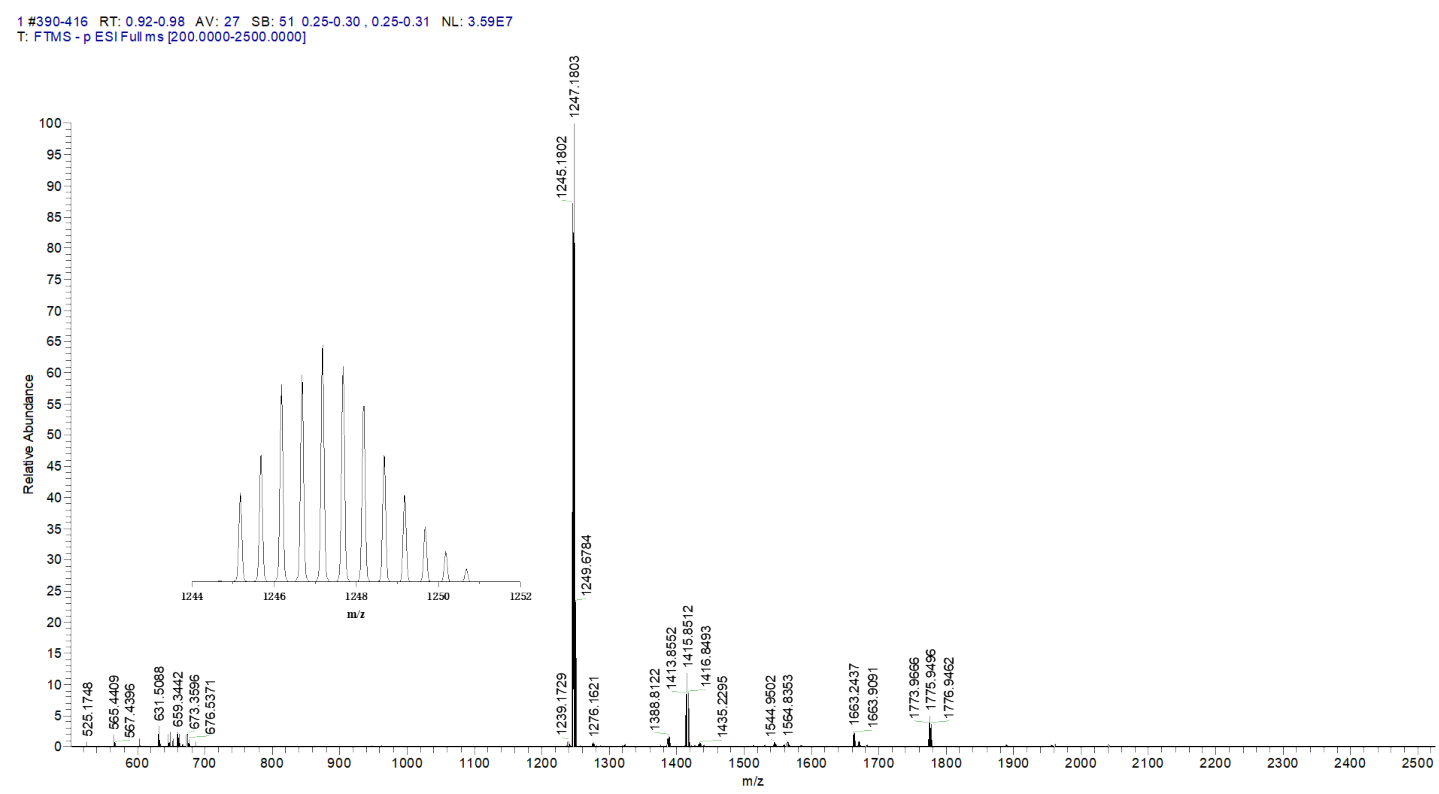

Figure S4. ESI-MS spectrum of compound 2 using the crystal precipitated from the solution of DMF. The inset is the enlarged part of $\mathrm{m} / \mathrm{z}=1247.18$. 


\section{FT-IR}

Both characteristic peaks of Lindqvist structure and porphyrin organic ligands are existed in compounds 1 . The sharp and strong bands at $950 \mathrm{~cm}^{-1}, 717 \mathrm{~cm}^{-1}$ are corresponding to the vibration of $\mathrm{V}=\mathrm{O}$ and $\mathrm{V}-\mathrm{O}-\mathrm{V}$ in the typical hexavanadate structure, respectively. The bands at $1051 \mathrm{~cm}^{-1}$ can be assigned to the vibration of C-O (Figure S5). Since the electron-withdrawing effect of the POMs, the hybrid exhibits highwavenumber shift compared to the $v(\mathrm{C}-\mathrm{O})$ of triol-porphyrin ligand Zn-Por-tris (Figure S6), which appeared at $1030 \mathrm{~cm}^{-1}$. Additionally, the sharp and strong peak at around $796 \mathrm{~cm}^{-1}$ represented for the para-disubstituted benzene, verifying the existence of porphyrin ligands in both compounds $\mathbf{1}$. Moreover, there is also a strong band at 998 $\mathrm{cm}^{-1}$, which can be attributed to the vibration of $\mathrm{Zn}-\mathrm{N}$.

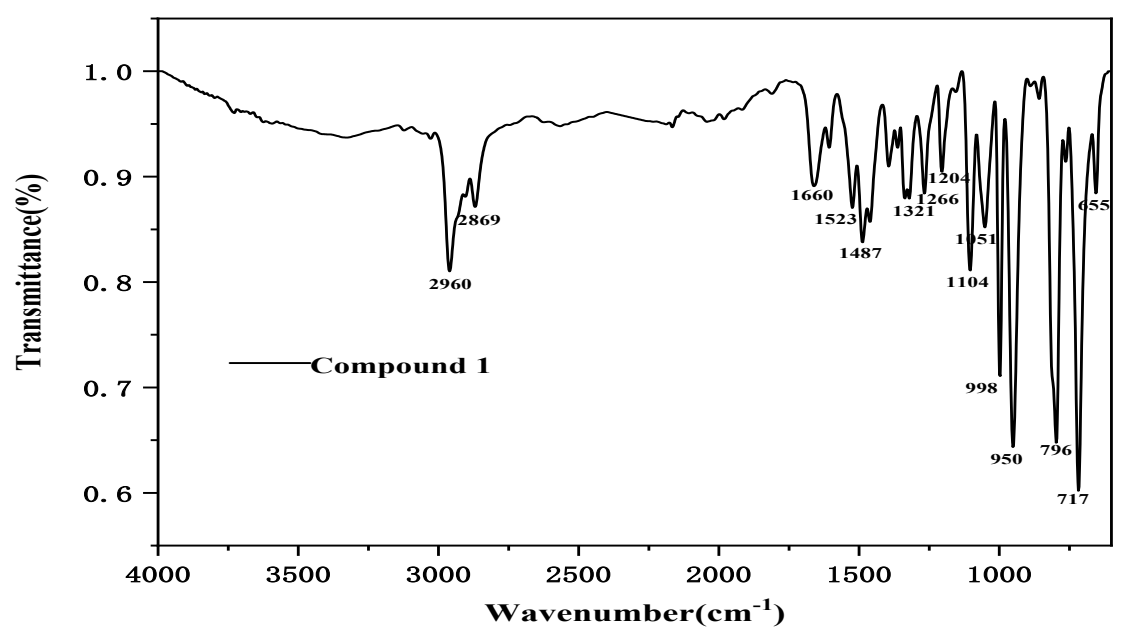

Figure S5. FT-IR spectrum of compound 1. 




Figure S6. FT-IR spectrum of Zn-Por-tris. 


\section{UV-Vis absorption and emission spectra}

The Zn-Por-tris and compound 1 present similar Soret bands at about $426 \mathrm{~nm}$, meanwhile, their doubled Q bands are both located at 557 and $600 \mathrm{~nm}$. The absorption positions of compound $\mathbf{1}$ are almost the same as the porphyrin precursor. This result indicates that there are no electron interactions between POMs and the porphyrin ligands at the ground state.

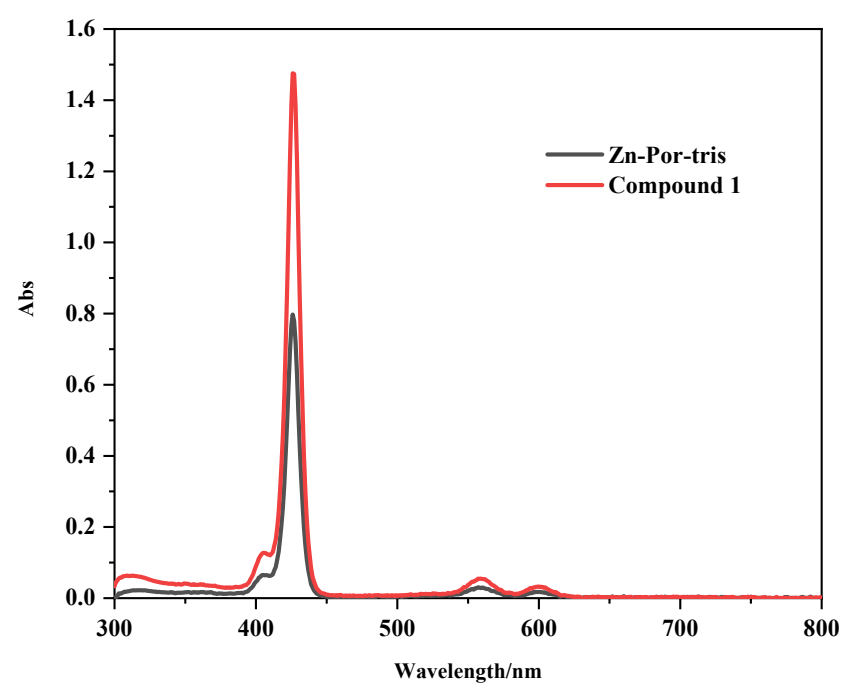

Figure S7. UV-vis absorption spectra of Zn-por-tris and compound $\mathbf{1 .}$

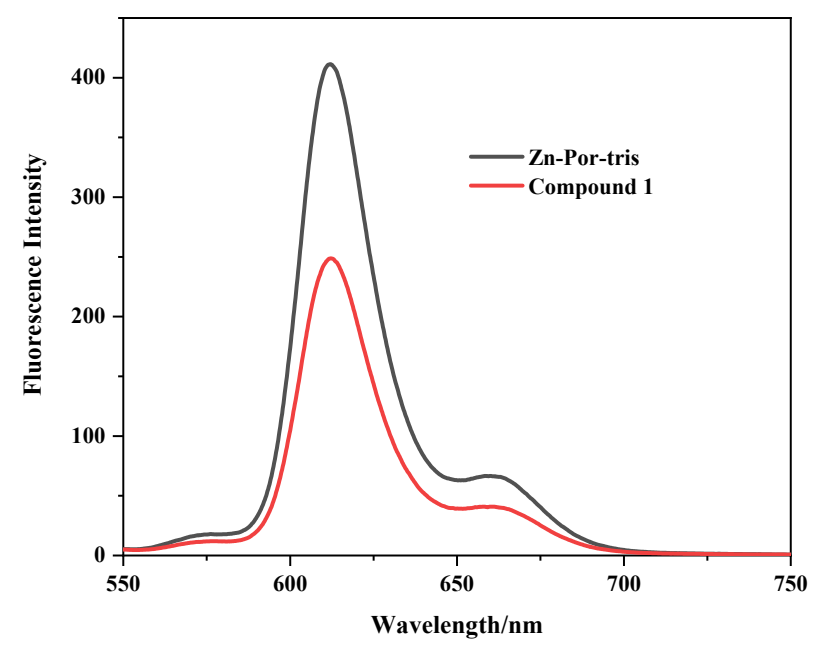

Figure S8. Emission spectra of Zn-Por-tris and compound $\mathbf{1}$ at the excitation wavelength of $429 \mathrm{~nm}$. 


\section{Photocatalytic activities}

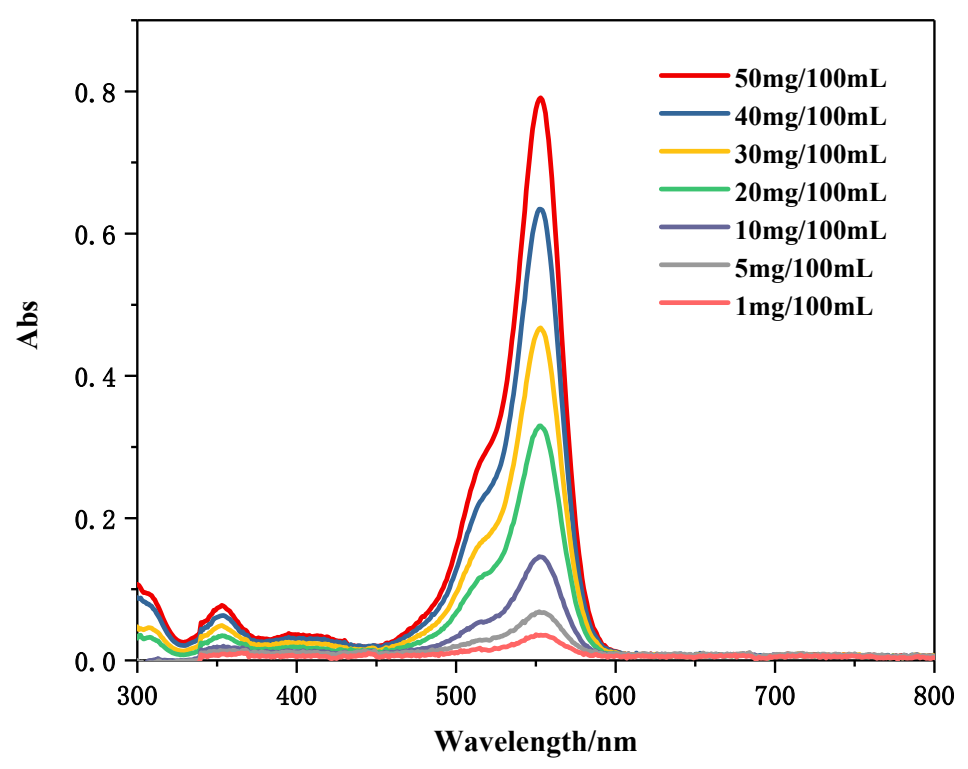

Figure S9. The standard curve of RhB in the aqueous solution.


Figure S10. The UV-Vis spectra changes without catalyst a) dark, b) under visiblelight. 

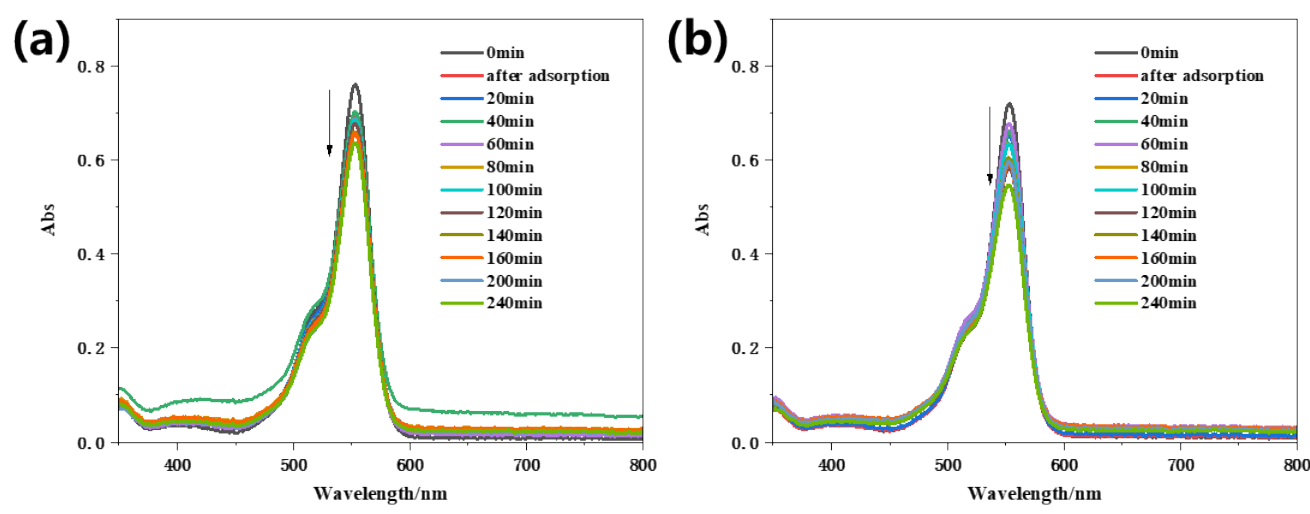

Figure S11. The UV-Vis spectra changes of Zn-Por-tris a) dark; b) under visiblelight.

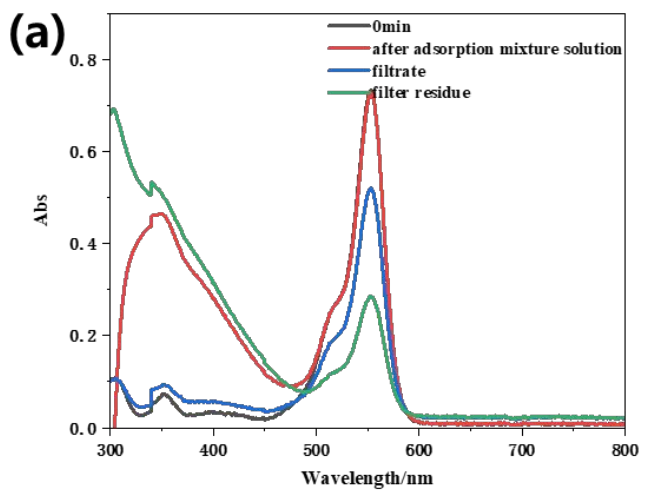

(b)
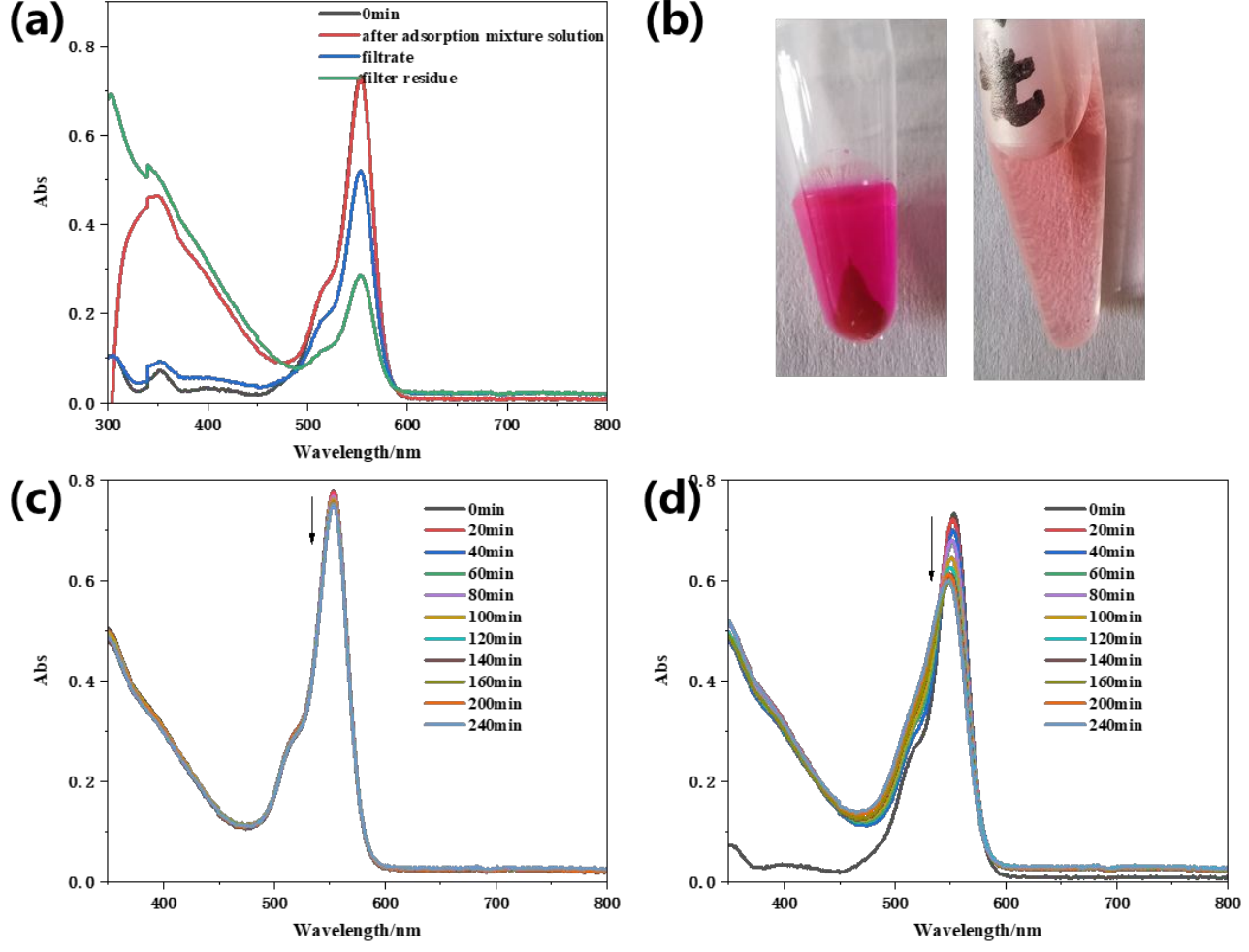

Figure S12. The UV-vis spectra changes of V10 a) with different solution; b) dark; c) under visible-light.

Using V10 as the catalyst, some red precipitates was generated in the solution after 1.5h dark adsorption (see Figure S12b left). After centrifugation, the UV-vis absorption of filtrate was showed in Figure S12a (the blue curve), exhibiting greatly decreased 
absorption. However, the filter residue could also be dissolved in water (see Figure $\mathrm{S} 12 \mathrm{~b}$ right), the UV-vis absorption was given as the green curve in Figure S12a. The green curve not only reveals the characteristic absorption of $\mathrm{RhB}$ at $553 \mathrm{~nm}$, but also reveals the characteristic absorption of V10 at $300-450 \mathrm{~nm}$, which means that the red precipitate contains both $\mathrm{V} 10$ and $\mathrm{RhB}$. This may be ascribed to some counter-ion exchange happened between $\mathrm{RhB}$ and $\mathrm{V} 10$, since $\mathrm{RhB}$ is a cationic dye, V10 with tetrabutylammonium counter-ion also has some solubility in water. So, exclude the effect of ion exchange, UV-vis was monitored directly from the reaction solution.

(a)



(c)

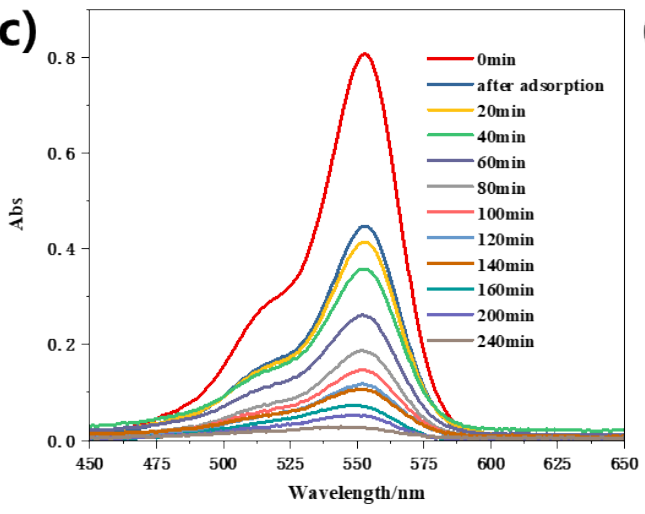

(b)

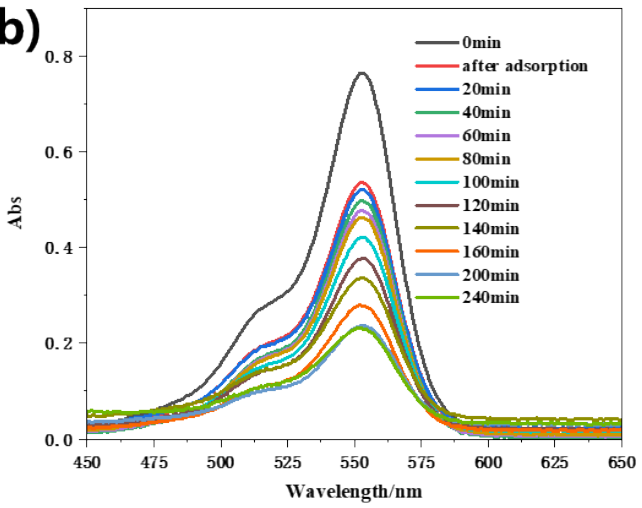

(d)

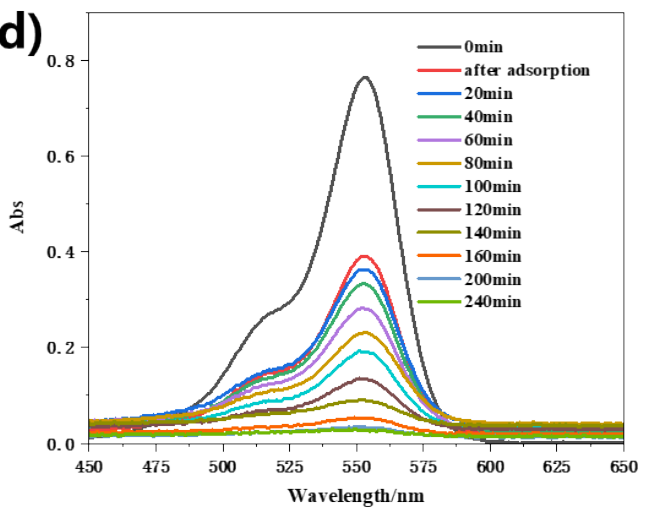

Figure S13. The UV-vis spectra changes of catalyst 1 under visible-light a) $3 \mathrm{mg}$; b) 6 $\mathrm{mg}$; c) $9 \mathrm{mg}$; d) $12 \mathrm{mg}$ 
(a)

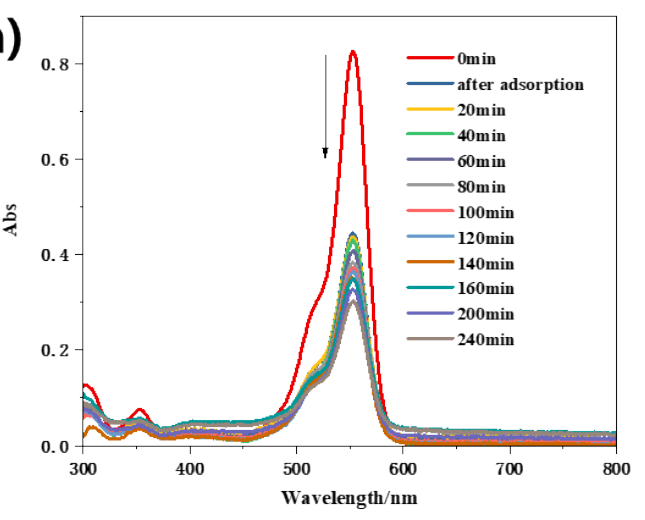

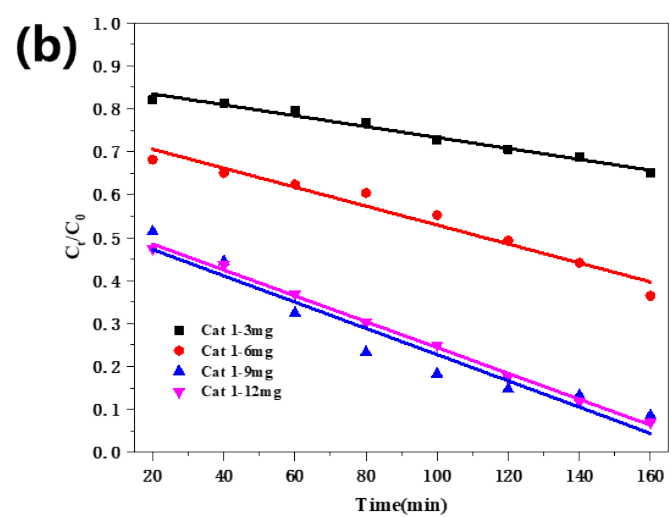

Figure S14. The UV-vis spectra changes of catalyst 1 a) under dark; b) linear changes of different catalytic amount of $\mathbf{1}$. 
7. FT-IR spectra before and after photocatalysis

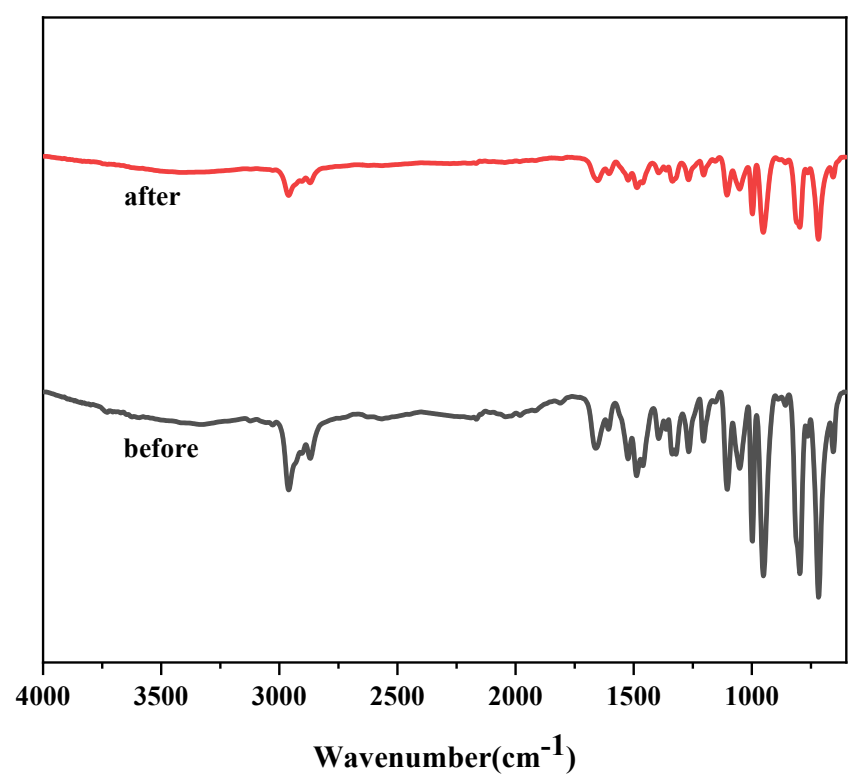

Figure S15. The FT-IR spectra of catalyst $\mathbf{1}$ before and after the catalytic process. 


\section{Energy bandgap calculation and $\mathrm{CV}$ results}
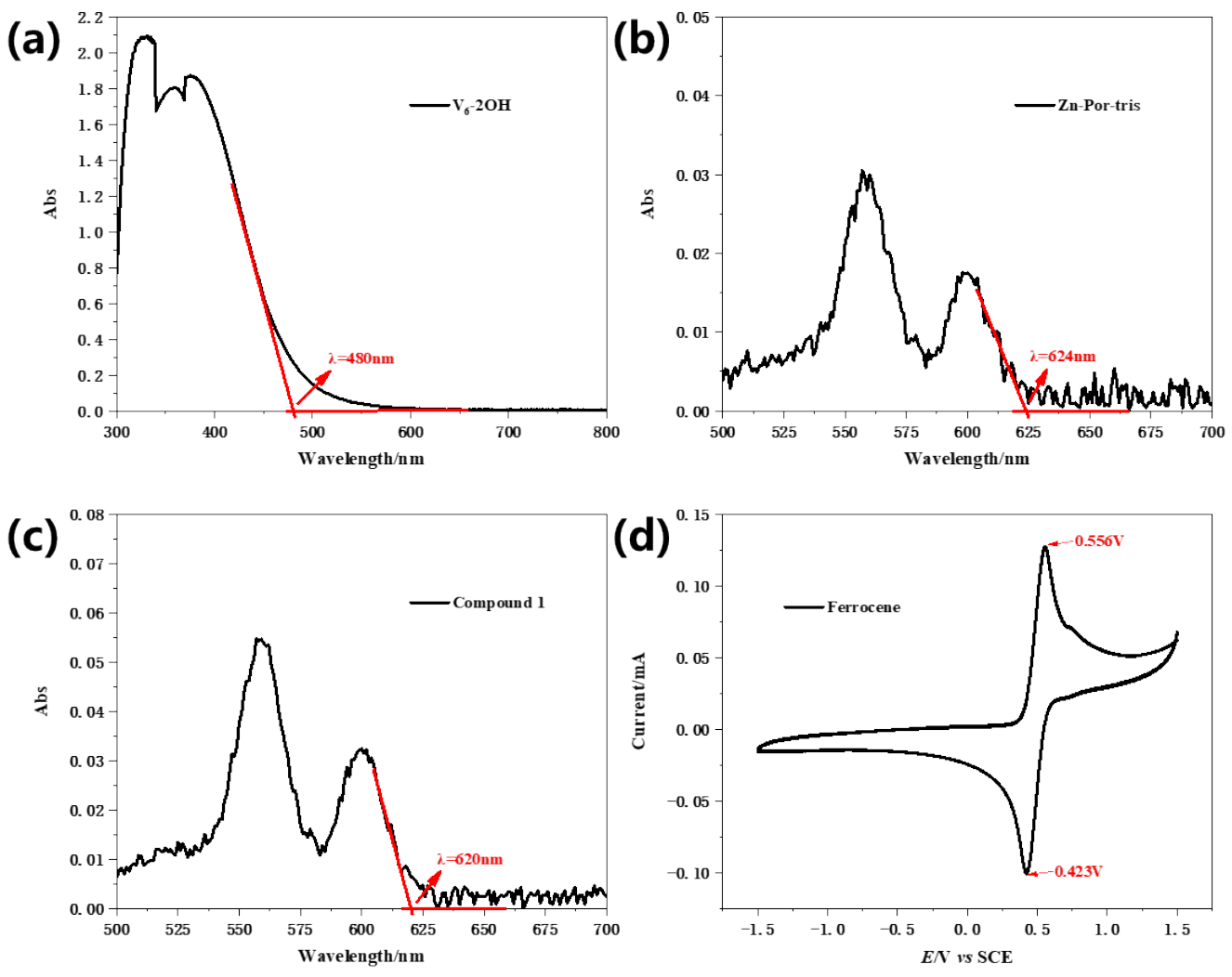

Figure S16. (a-c) UV-vis absorption edge of V6, Zn-Por-tris, compound 1 respectively.

(d) cyclic voltammetry curve of ferrocene standard. V6 represents $\left(\mathrm{Bu}_{4} \mathrm{~N}\right)_{2}\left[\mathrm{~V}_{6} \mathrm{O}_{13}\left\{\left(\mathrm{OCH}_{2}\right)_{3} \mathrm{CCH}_{2} \mathrm{OH}\right\}_{2}\right] .{ }^{1}$ 


\section{Table S3}

Table S3. Energy bandgap and HOMO-LUMO levels

\begin{tabular}{cccccc}
\hline Compound & $\lambda_{\max }(\mathbf{n m})^{\mathbf{a})}$ & $\mathbf{E g}(\mathbf{e V})^{\mathbf{b})}$ & $\mathbf{E r e d}(\mathbf{V} \text { vs SCE})^{\mathbf{c})}$ & $\mathbf{E}_{\mathbf{L U M O}}(\mathbf{e V})^{\mathbf{d})}$ & $\mathbf{E}_{\text {HoMo }}(\mathbf{e V})^{\mathbf{e})}$ \\
\hline Zn-Por-tris & 624 & 1.99 & -1.22 & -3.09 & -5.08 \\
Compound 1 & 620 & 2.0 & -1.15 & -3.16 & -5.16 \\
$\mathrm{~V}_{6}$ & 480 & 2.58 & -0.47 & -3.84 & -6.42 \\
\hline
\end{tabular}

a). Estimated from the absorption edge of UV-vis; b). estimated from the equation of $\mathrm{E}_{\mathrm{g}}=1240 / \lambda$ ( $\lambda$ is absorption edge); $\mathrm{c}$ ). measured from the onset reduction potential of $\mathrm{CV} ; \mathrm{d})$. estimated from equation $\mathrm{E}_{\mathrm{LUMO}}(\mathrm{eV})=-\left[\mathrm{E}_{\mathrm{red}}-\mathrm{E}_{\mathrm{FOC}}+4.8\right] \mathrm{eV}, \mathrm{E}_{\mathrm{FOC}}=\left(\mathrm{E}_{\mathrm{ox}}+\mathrm{E}_{\mathrm{red}}\right) / 2$ of ferrocene used as standard. e). $\mathrm{E}_{\mathrm{HOMO}}(\mathrm{eV})=\mathrm{E}_{\mathrm{LUMO}}-\mathrm{E}_{\mathrm{g}}$ 


\section{References}

1. Chen, Q.; Goshorn, D. P.; Scholes, C. P.; Tan, X. L.; Zubieta, J. Coordination compounds of polyoxovanadates with a hexametalate core. Chemical and structural characterization of $\left[\mathrm{VV}_{6} \mathrm{O}_{13}\left[\left(\mathrm{OCH}_{2}\right)_{3} \mathrm{CR}\right]_{2}\right]^{2-},\left[\mathrm{VV}_{6} \mathrm{O}_{11}(\mathrm{OH})_{2}\left[\left(\mathrm{OCH}_{2}\right)_{3} \mathrm{CR}\right]_{2}\right],\left[\mathrm{V}_{4}^{\mathrm{IV}} \mathrm{VV}_{2} \mathrm{O}_{9}(\mathrm{OH})_{4}\left[\left(\mathrm{OCH}_{2}\right)_{3} \mathrm{CR}\right]_{2}\right]^{2-}$, and $\left[\mathrm{V}^{\mathrm{IV}}{ }_{6} \mathrm{O}_{7}(\mathrm{OH})_{6}\left\{\left(\mathrm{OCH}_{2}\right)_{3} \mathrm{CR}\right\}_{2}\right]^{2-}$. J. Am. Chem. Soc. 1992, 114, 4667-4681.

2. Wu, P.; Chen, J.; Yin, P.; Xiao, Z.; Zhang, J.; Bayaguud, A.; Wei, Y. Solvent-induced supramolecular chirality switching of bis-(trisalkoxy)-hexavanadates. Polyhedron 2013, 52, 13441348.

3. Wessendorf, F.; Gnichwitz, J.-F.; Sarova, G. H.; Hager, K.; Hartnagel, U.; Guldi, D. M.; Hirsch, A. Implementation of a Hamiliton-Receptor-Based Hydrogen-Bonding Motif toward a New Electron Donor-Acceptor Prototype: Electron versus Energy Transfer. J. Am. Chem. Soc. 2007, 129, 16057-16071. 